\title{
The Impact of Organizational Justice at Organizational Conflict Level between Its Parties: A Field Study in Jordan Public Administration
}

\author{
Hamdan Salim AL Awamlah ${ }^{1}$ \\ ${ }^{1}$ Department of Business Administration, Faculty of Business, Al- Balqa' Applied University (BAU), Jordan \\ Correspondence: Dr. Hamdan Salim AL Awamlah, Associate Prof., Department of Business Administration, Faculty \\ of Business, Al- Balqa' Applied University (BAU), Jordan. E-mail: h.alawamlah@yahoo.com
}

Received: August 26, 2013

Accepted: September 17, 2013

Online Published: November 8, 2013

doi:10.5430/ijba.v4n6p62

URL: http://dx.doi.org/10.5430/ijba.v4n6p62

\begin{abstract}
This study aims to investigate how organizational justice affects organizational conflicts between its parties, since large part of organizational conflict is attributed to prevailing justice level in organizations, consequently there is a wide range for institutions to create within organizational conflict management through practicing several efforts to establish justice. The study carried out a brief description of organizational justice, and organizational conflict types, after reviewing the most important researches and related studies. Variables, hypothesis, and virtual model were identified to match with study objectives. Data was collected from (366) respondents who are employed in (6) governmental institutions. Impacts and relationship nature test was made based on multiple regression, and correlation factor (Sperman) with confidence level $(\mathrm{P}<0.05)$. The results and interpretation analyzes proved to higher acceptance of model variables but they were varied in their types, strength and direction. The study concluded that there is a possible opportunity to depend organizational justice to interpret organizational conflict level. The study also found strong evidences that indicate the fragility of organizational justice in Jordanian public administration, and high level of organizational conflict.
\end{abstract}

Keywords: organizational justice, organizational conflict, Jordan, procedural justice, distribution justice, transaction justice

\section{Introduction}

It became a contemporary concept to understand how organizations distribute position, pride values, power and privileges. In addition, to understand that they are environments to create, values, perceptions and ideologies, so they work to organize tools, to build attitudes, and to direct tendencies and desires, in order to have employees behavior that consist with its mission and culture, for the purposed of achieving commodity or service best production level of (Awamleh, 3: 2008). Therefore organizations pay their attention to employees care to form and strength their belief that their goals will be achieved in a better way only within their organizations (Kerreman \& Alvess, 60-70: 2001)

According to (Chris Argyris), formal organization requirements are not compatible with individual aspirations, ambitions and private goals (Harem, Hussein,1997: 61), which generates their sense and trends toward organizational justice, or what is known as Justice Sensitivity, according to their sensitivity to justice due resulted by individuals differences (Hawass, 45:2003). So, employees who feel the organizational justice in their organizations they re-form their self-perceptions in order to adapt with organization culture and its mission (Albert \& Duttons 2000:13-17). Then organization interests are achieved, and a competitive advantage is added, even under a weak presidential control.

Organizational conflict is considered a natural and inevitable, organizational phenomenon, that accompany human interaction within any organization. It can be within individual himself level, or between individuals, or between the individual and groups, or among groups, so that it cannot get rid of it, but must be managed and worked out to achieve the highest benefit of it (AL Balwi, Abdel-Moneim Gaber, 2009). By considering organizational conflict as one the main interaction forms and its existence at a certain level is deemed a motivation, and one of the driving sources that drives force to raise individuals and groups performance, but the increasing intensity of conflict, or its high level will result in a negative effect on the level of performance and then it undermines organization effectiveness of the (Kashlav 2009: 1) 


\section{Importance of the Study}

The importance of studying the impact of organizational justice on organizational conflict from the aspect of the academic process, lack of studies that discussed organizational justice impact analysis on organizational conflict at local and Arabic levels, according to what was made available to the researcher. And the absence of any study on Jordan management. From the practical (applied) aspect because of their link with influence and organizational strength, and organizations effectiveness achievement that push the society towards progress and prosperity through the availability of goods and services, in addition to raising management's ability to analyze and understand human behavior, control and predict, to direct it and to ensure government organizations effectiveness, which leads society progress process.

Below some of the factors that highlight the importance of this study:

1) The real need for scientific research that address the dimensions of organizational justice and its impact on organizational conflict in its different forms.

The importance of applied sector within the aspects of disparity between organizations and inside the institution itself in various privileges and transactions. and the sagging of this sector and management inability to make required change, which through increasing organizations effectiveness, in an era that is characterized by instability, rapid change and workers high voices in many governmental organizations in Jordan, which express its lack of justice sense and their calls for management leaders exclusion from their functional posts.

A scientific importance represented by its concluded results after impact analysis between the associated variables with two phonemes and presenting recommendations accordingly, to be used upon decisions making.

The possibility of using standard organizational justice in the analysis of organizational conflict for good management of these conflicts, according to (David Alman, 2011: 1)

\section{Problem of the Study}

Human factor in organizations is deemed as driver and magnifier of organization factors and provider of its effectiveness. The literature related to study phenomena showed that there is a need to study the phenomena, environmental and organizational variables that produce employees behavior in organizations. Organizational justice is now deemed as the future basic function of human resources management and basic mean for creation social realities in organizations, that organization have to seek to achieve in highest possible level, and work on conflict management in its various forms, within the level of achieved competition for motivating towards highest level of performance, production and to maintain a certain level of conflict in order not to be more worse and all its negative impacts become negative on employees and organization.

The research problem can be expressed in the following questions:

1) To what level do Jordanian administration employees feel the organizational justice?

2) What is the organizational conflict level according to its parties in Jordanian governmental organizations?

3) What is the impact of employees feeling with organizational justice on organizational conflict according to its parties?

4) Is there any associated relationship between organizational justice and organizational conflict?

\section{Study Hypotheses}

There is a significant relationship between organizational justice as a whole independent variable and organizational conflict level according to its parties in Jordanian government organizations as a whole dependent variable.

There is a significant impact $\mathrm{p}<0.05$ level of organizational justice as an independent multi-dimensional variable at organizational conflict level according to its parties in Jordanian government management as a whole dependent variable

Sub- hypotheses are derived as follows:

There is a significant impact under the moral level of significance $p<0.05$ for procedural fairness at the level of organization conflict as related to its parties.

There is significant impact under the moral level of significance $\mathrm{p}<0.05$ for the distributive justice at the level of organization conflict as related to its parties. 
There is significant impact under the moral level of significance $p<0.05>$ for justice of deals at the level of organizational conflict as related to its parties.

There is an effect is of moral significance under the level of significance $p<0.05$ of the organizational justice as an overall independent variable on the level of organizational conflict as its parties dependent variable and multi-dimensional ramifications of the following assumptions:

There is a moral effect of significance under the level of significance $p<0$. 05 of the organizational justice as an independent variable, on the overall level of organizational conflict, at the individual level.

There is a moral effect significance under the level of significance $\mathrm{p}<0.05$ of the organizational justice as a independent variable' on the overall level of organizational conflict between individuals.

There is a moral effect of significance under the level of significance $p<0.05$ of the organizational justice as an independent variable on the overall level of organizational conflict between the individual and the community.

There is a moral effect of significance under the level of significance $p<0.05$ of organizational justice as an Independent variable on the overall level of organizational conflict between organizational groups.

\section{Study Variables}

The study model consists of seven main variables, they are defined and measured through (52) paragraph included in the study questionnaire. The variables were distributed according to two dimensions, namely: (organizational justice, and organizational conflict).

Table 1. Study variables

\begin{tabular}{|c|c|c|c|c|c|}
\hline \multirow[b]{2}{*}{ Main Variables } & \multirow[b]{2}{*}{ Sub-variables } & \multirow[b]{2}{*}{ Type } & \multicolumn{3}{|c|}{ Paragraphs } \\
\hline & & & $\begin{array}{c}\text { List of } \\
\text { question }\end{array}$ & $\begin{array}{c}\text { Number of } \\
\text { questions }\end{array}$ & Total \\
\hline \multirow{3}{*}{$\begin{array}{l}\text { Organizational } \\
\text { Justice (1) }\end{array}$} & Justice procedures & Independent & $1-3$ & 3 & \\
\hline & Distributive justice & Independent & $4-7$ & 4 & \\
\hline & Transactions Justice & Independent & $8-11$ & 4 & \\
\hline & & & & & 11 \\
\hline \multirow{7}{*}{$\begin{array}{c}\text { Organizational } \\
\text { Conflict }\end{array}$} & & Dependent & $12-19$ & 8 & \\
\hline & Conflict within the individual & & & & \\
\hline & Conflict between individuals & Dependent & $20-34$ & 15 & \\
\hline & Conflict between individual and & & & & \\
\hline & $\begin{array}{ll}\text { group }\end{array}$ & Dependent & $35-42$ & 7 & \\
\hline & Conflict between groups & & & & \\
\hline & & Dependent & $43-53$ & 10 & \\
\hline
\end{tabular}

(1) Niehoff \& Moorman, 1998 Scale that was tested in several Arab and foreign environments was adopted.

Instrument reliability and its statements homogeneity were tested using the split half-parts (divide questionnaire to two groups of odd and even paragraphs, and testing reliability among them).

Reliability coefficient $=$

(r) $\mathbf{N}$

$\mathbf{r}(\mathbf{N}-1)+1$

Where $\mathrm{N}$ is the number questionnaire, $\mathrm{R}$ is Pearson correlation coefficient between parts. Pearson correlation coefficient value between the two halves of the questionnaire is $(0.72)$ and therefore:

$$
\text { Reliability coefficient }=2(0.72) \quad=0.83
$$

Content validity was also tested according to the following equation:

$$
0.92=\sqrt{ } \text { Validity Coefficient }=\sqrt{ } \text { Reliability coefficient }=\sqrt{ } 0.83
$$


Table 2. Instrument reliability coefficient and validity

\begin{tabular}{cccccc}
\hline $\begin{array}{c}\text { The correlation } \\
\text { coefficient }\end{array}$ & $\begin{array}{c}\text { Reliability } \\
\text { coefficient }\end{array}$ & $\begin{array}{c}\text { Validity } \\
\text { Coefficient }\end{array}$ & $\begin{array}{c}\mathrm{T} \\
\text { calculated }\end{array}$ & $\begin{array}{c}\mathrm{T} \\
\text { tabulated }\end{array}$ & Sig. Level \\
\hline 0.72 & 0.83 & 0.92 & 6.51 & 1.69 & 0.05 \\
\hline
\end{tabular}

\section{Study Objectives}

This study aims to achieve the following objectives:

To explore the correlation existence extent between study two variables: organizational justice and organizational conflict.

To find out employees feeling level (sensation) in Jordanian governmental administration with every dimension of organizational justice dimensions.

To find out the conflict level that employees feel in Jordanian governmental administration

To measure the impact of organizational justice on organizational conflict and the contribution of each dimension in interpretation organizational conflict phenomenon in its different types (according to its parties), excluding organizations conflict

1- To discuss the practical applications of research results in order to make suggestions that will enable decision makers (managers) to use organizational justice as a method for conflict analysis, conflict management or control the same within conflict desirable limits or creative competition.

2- $\quad$ To provide researchers with a study for in the field of organizational behavior as a basis for other studies in the absence of researches that handled the two phenomena as quite rare in Jordan as well the Arab world.

\section{Population and Study Sample}

The study population represents several forms of public facilities in terms of its size and work nature and it is artificial personality, its financial and managerial independent. Random stratified sample was selected from the study population, which consists of six governmental departments with (3108) employees, the sample size is (366) employee that is $11.77 \%$ of study population as described in the following table:

Table 3. Study sample

\begin{tabular}{ccccccc}
\hline No & $\begin{array}{c}\text { Management Name } \\
\text { of the }\end{array}$ & $\begin{array}{c}\text { Number of } \\
\text { employees }\end{array}$ & $\begin{array}{c}\text { Distributed } \\
\text { Questionnaires }\end{array}$ & $\begin{array}{c}\text { Collected } \\
\text { questionnaires }\end{array}$ & $\begin{array}{c}\text { Questionnaires } \\
\text { used for analysis }\end{array}$ & Percent \\
\hline $\mathbf{1}$ & $\begin{array}{c}\text { Ministry of Higher } \\
\text { Education and } \\
\text { Scientific Research }\end{array}$ & 220 & 70 & 63 & 50 & $22.72 \%$ \\
\hline $\mathbf{2}$ & $\begin{array}{c}\text { Ministry of Public } \\
\text { Works }\end{array}$ & 570 & 60 & 58 & 51 & $08.94 \%$ \\
\hline $\mathbf{3}$ & $\begin{array}{c}\text { Ministry of } \\
\text { Planning and } \\
\text { International } \\
\text { Cooperation - } \\
\text { Department of } \\
\text { Statistics }\end{array}$ & 563 & 75 & 68 & 61 & $10.83 \%$ \\
\hline $\mathbf{4}$ & $\begin{array}{c}\text { Accreditation } \\
\text { Commission of } \\
\text { Higher Education }\end{array}$ & 47 & 30 & 25 & 20 & $42.55 \%$ \\
\hline $\mathbf{5}$ & $\begin{array}{c}\text { Balqa Applied } \\
\text { University / } \\
\text { Headquarter }\end{array}$ & 1562 & $\mathbf{2 0 0}$ & 182 & 156 & $09.98 \%$ \\
\hline $\mathbf{6}$ & $\begin{array}{c}\text { Princess Alia } \\
\text { College }\end{array}$ & 146 & 35 & 32 & 28 & $19.17 \%$ \\
\hline Total & $\mathbf{3 1 0 8}$ & $\mathbf{4 7 0}$ & $\mathbf{4 2 8}$ & $\mathbf{3 6 6}$ & $\mathbf{1 1 . 7 7 \%}$ \\
\hline
\end{tabular}




\section{The Organizational Justice}

\subsection{Concept of Justice}

Justice in general is enabling right owner obtain his right through nearest, and easiest ways, or to give everyone what he deserves (Shaima, 2008). It is an old humanitarian principle, based on mind and justice feel. Mind and consideration took different forms within peoples. Romans (the law of peoples), and Greece (the law of nature), English (the conscience of the King), Muslims, mind and wisdom in legislation. (Rafii, Mustafa, 2010)

Justice is a value that individuals, groups, and even nations struggle to attain the highest of its levels, since human justice is proportional, and there is no absolute justice on the earth, but we can talk about a humanitarian ideal justice.

The idea of organizational justice stems from Adams (Adams: 1963-1965) justice theory which assumes that justice and injustice are provisions derived from comparisons between self and others on the basis of inputs and outputs (Awamleh, 2008: 12), or on a personal level, provided by individual as knowledge or effort and outcome attained. The term has been used also by (Greenberg) and (Bies) according to individual imagination and reactions to organization justice function (Lee, 2003:21).

\subsection{Organizational Justice Dimensions}

Individuals tendency to compare their situation with their colleagues at work or staff awareness of justice within the organization based on inputs and outputs and the result of such perception in the form significant behaviors on organization effectiveness. The researcher intended to study the major dimensions of organizational justice that agreed by the two researchers: (Rego \& Cunha, 2006:7), and Arab researchers (Awamleh 2008: 13), (Zayed, 2006: 557-615) (Yusuf 1999: 89-107) (Ajami and others, 2000: 193-224) (Atwi 2007) (Wadi, Rushdie: 2007), these dimensions are:

\subsubsection{Distributive Justice}

Distributive justice refers to equality theory. Distributive justice means perceived justice upon resources distribution by organization, organization output, by workers and their assessment of final resources distribution in the organization. The justice distribution depends on three rules as defined by (Organ: 1988:64), (Al-Atwi, 2007: 4) are:

- Equality base: it refers to giving rewards on the basis contribution size with assumption that individuals are equal regarding other factors.

- Quality base: it means that all employees obtain benefits from the services offered to them (health insurance for example) without discrimination between them according to individual characteristics or performance.

- Need base of: it refers to providing individuals with any urgent need with assumption that all other factors are equal.

\subsubsection{Procedural Justice}

Procedural justice indicates the behavior, processes and procedures used in decision-making in workplace and that lead to output distribution on employees. Organizational justice will not be achieved unless individuals believe in application six rules of procedural justice as: capability of correction, representation base, neutral base, ethical base, accuracy base, and harmony or consistency base.

\subsubsection{Interactional Justice}

Interactional Justice are considered as an extension of procedural justice concept, and associated with managers behave with subordinates, or in other words, the quality of handling decision makers that take one of two forms:

Interpersonal justice and Informational Justice.

The first form refers to manager respect and appreciation of his subordinates'. The second relates to the information and clarifications provided by the manager to the staff regarding the distributing decisions procedures in a reliable style, or in other words the knowledge provided to employees regarding procedures and outcomes related to. (Lee, 2003:30). These organizational justice dimensions are connected and integrated and form the perceived image of organizational justice by employees, which is considered one of the most important factors affecting organization effectiveness, and is an important approach for modern organizations as it relates to the behavior of individuals in organizations and career climate.

\subsection{Organizational Conflict}

\subsubsection{Organizational Conflict Concept}

Conflict word in a language is generated from the word struggle, which means to be kicked down. A conflict among people is a conflict, strife or discord (Balawi, 2005: 1). The conflict term taken from the Latin word conflicyus which 
is means strife together. The use of force, and in old English language conflict means the process of beating or knocking or fight or strife (Al-Otaibi, 2006: 12-11).

Conflict in general is a universal truth, humanity, and human necessity hidden in human creation nature and life (Qutb, Muhammad) It started since the beginning of humanity represented by Cain killing his brother Abel. Conflict is seen from different views, social, economic, cultural, political and organizational managerial aspect, called organizational conflict (Sarayrah, Aktam, 2008: 71).

Deeb, (1987: 7) considers conflict is a deliberate and direct conflict between individuals or groups for the sake of single goal. The desire of one of conflict parties appears to defeat the other party regardless of reaching the target. This definition leads to the same direction of definition by (March \& Simon,: 1958 56-62), where they view conflict as a state of change in usual behavioral patterns, as a result of interests contradicting between relationship parties, which lead to an imbalance in decision-making system, and disruption of work process, and then a threat organization stability of the (cited in, Al Namr 1994: 47-48).

Simon \& March assure that conflict is inherent in organizations, and cannot be considered as a sickness phenomenon, because organizations nature, creates conflict positions (Wishahi, Marwan, 2004: 17-16). Griffin \& Moorhead (2006) define conflict as "a dispute between groups or t parties. Rahim \& Shapiro, (2002) define conflict as an interactive process appear in incompatibility or rejection or repulsion that occurs between - or inside -social entities that is individual or group or organization. (Rifai, Rajab, 2009: 16). The researcher defines conflict as "a perceived conflict between social entities or inside these entities, of different level due to personal or organizational reasons, that produce positive or negative effects depending on the ability to control and manage it". This definition refers to human perceived nature and its severity degrees, parties, causes, form of its potential impacts, and the possibility to manage (Alnamr, 1994: 49 - and Wishahi, 2002: 18 -Rifai, Rajab, 2009: 17)

\subsubsection{Conflict Approaches (Conflict Theories)}

Writers differ across time stages in conflict perception in terms of its effects and methods to cope with, despite of its determinism nature social, and its existence in any system, to the end that it can acquire the status of legitimacy, as (Bernard) said. The conceptual composition of management freedom in changeable environment includes social patterns, characterized by negotiation, tension and conflict. Therefore the researchers view regarding organizational conflict concept is different, and each of them chose one of the following approaches: (Sarayreh, 2008: 71):

\subsection{Organizations Conflict Forms}

Researchers differ in their classification of organizational conflict of types or forms within organizations, many studies discussed its forms in brief, due to contrast in its perception, these classification are as follows:

Table 4. Organizational conflict forms within organizations

\begin{tabular}{|c|c|c|c|c|c|c|}
\hline $\begin{array}{l}\text { According to } \\
\text { Its parties }\end{array}$ & $\begin{array}{l}\text { According to } \\
\text { organizational } \\
\text { attitudes }\end{array}$ & $\begin{array}{l}\text { According } \\
\text { to its level }\end{array}$ & $\begin{array}{l}\text { According } \\
\text { to its } \\
\text { effects }\end{array}$ & $\begin{array}{l}\text { According to } \\
\text { organization }\end{array}$ & $\begin{array}{l}\text { According to } \\
\text { planning }\end{array}$ & $\begin{array}{l}\text { According to } \\
\text { its resources }\end{array}$ \\
\hline $\begin{array}{l}\text { Conflict } \\
\text { inside } \\
\text { individual } \\
\end{array}$ & \multirow{2}{*}{ Vertical Conflict } & \multirow{2}{*}{$\begin{array}{l}\text { Desired } \\
\text { conflict } \\
\text { level f }\end{array}$} & \multirow{2}{*}{$\begin{array}{l}\text { Conflict } \\
\text { with } \\
\text { Negative } \\
\text { effects }\end{array}$} & \multirow{2}{*}{$\begin{array}{l}\text { Structured } \\
\text { conflict }\end{array}$} & \multirow{2}{*}{$\begin{array}{l}\text { Planned } \\
\text { Strategic }\end{array}$} & Emotional \\
\hline $\begin{array}{c}\text { Conflict } \\
\text { between } \\
\text { individuals }\end{array}$ & & & & & & For the source \\
\hline \multirow{3}{*}{$\begin{array}{c}\text { Conflict } \\
\text { between } \\
\text { Individual \& } \\
\text { group }\end{array}$} & \multirow{4}{*}{$\begin{array}{l}\text { Horizontal } \\
\text { conflict }\end{array}$} & $\begin{array}{l}\text { Conflict } \\
\text { level } \\
\text { higher }\end{array}$ & \multirow{4}{*}{$\begin{array}{l}\text { Conflict } \\
\text { with } \\
\text { positive } \\
\text { effects }\end{array}$} & \multirow{4}{*}{$\begin{array}{c}\text { Conflict } \\
\text { unstructured }\end{array}$} & \multirow{4}{*}{ Unplanned } & $\begin{array}{c}\text { For } \\
\text { understanding }\end{array}$ \\
\hline & & $\begin{array}{l}\text { than the } \\
\text { desired }\end{array}$ & & & & For the \\
\hline & & Conflict & & & & \\
\hline $\begin{array}{l}\text { Conflict } \\
\text { between } \\
\text { groups }\end{array}$ & & $\begin{array}{l}\text { level less } \\
\text { than } \\
\text { desired }\end{array}$ & & & & Intellectual \\
\hline
\end{tabular}

Source: prepared by the researcher 
The researcher will depend on the classification based on conflict parties or the so-called by some due to its level, with emphasis that there is another type occurred between organizations which is not included within this category, and conflict forms according to its parties will only be included within organizations, and these forms are:

\subsubsection{Self-Conflict (Personal)}

Self conflict happened when an individual is exposed to frustration situations, that prevents achievement of his objectives, or when individual is not sure of what is required, or required role contrary to others expectations, or when he is requested to compel tasks beyond his abilities and energies (Al-Otaibi, Tariq 0.2006: 25). Or when individual is requested to choose alternatives contrary to his objectives, expectations, values, and believes, and he is forced to choose one of the alternatives. (Shalabi, Zuhair, 2011: 98). Despite that individual is field of this conflict, but other attitudes, and roles may play a role in creating this conflict, which may result in a conflict between individual and others.

\subsubsection{Conflict between Individuals}

This form of conflict mainly occurs due contrast between individuals personalities because genetic factors differences and acquired factors that form human personality, especially cultural and social factors, economic, political and intellectual (Harem, Hussein, 1997:51).

This type of conflict is one of the most common types of conflict prevalent in organizations and its effects may extend to other organizations parties, so management should use appropriate strategies to manage it for the sake of reducing its negative effects on work and then organizations effectiveness (AL Namr, 1994: 50) (Shalabi Zuhair, 2011: 100)

\subsubsection{Conflict between Individual and the Group}

This type of conflict arises due to individual inability to match group standards, either he adapts himself with group standards or the group started it attempts to affect him through several mechanisms that cause conflict with the group (Bruce. Hilton: 2009), where each group has regulations and behavioral patterns that binding its members. If they contradicted with individual goals or if he subjected to pressures in order to compel the organization requirements, the individual will be motivated to engage in conflict with the group. This type of conflict does last for long periods of time (Al-Otaibi, Tariq, 2006: 29).

\subsubsection{Inter group Conflict}

The organization consisted of many groups, formal and informal, regardless of the reasons for its composition, that are:

Functional Groups: that is managerial units that form organizational structure and task forces which are formed to accomplish a specific work. Interest and Friendship Groups which are formed due to interests and beliefs or activities interdependence. Committees which are a temporary team-work formed to study a specific topic. Informal Groups: which are automatically generated between individuals based on their common interest (AL Maghrabi, Kamil, 1995: 179-180).

Conflict between groups, formal organizations in particular is common, in organizations because organizations achieve their objectives and effectiveness by two forms: - (Shalabi, 2011: 102-103)

\subsubsection{Conflict Levels}

Conflict levels means the degree of difference felt by individuals in workplace, which is differ from one person to another, according to individual differences, since its level could be either low, medium or high (Rifai, Rajab, 2009: 18). (Al-Otaibi, 2006: 181) indicated that organizational conflict has three levels:

A - Desired conflict Level, which is called the optimal level of conflict.

$\mathrm{B}$ - Conflict level that is less than the desired.

C - Conflict level that is higher than the desired.

Maghrabi (1995: 312), argued that management should intervene in two cases:

First: when conflict level of increased above the desired, so management intervenes here by reducing it to the desired level.

Second: when its level dropped from the desired level the management intervenes to activate the desired level. 
The following table shows levels of conflict and the results of each level and the characteristics of the organization, and a link to organization interaction.

Table 5. The relationship between conflict levels, its consequences and organization characteristics and its effectiveness

\begin{tabular}{ccccc}
\hline Situation & Conflict level & $\begin{array}{c}\text { Conflict } \\
\text { results }\end{array}$ & Characteristics of the organization & $\begin{array}{c}\text { organization } \\
\text { Interaction }\end{array}$ \\
\hline A & Nil or low & Harmful & $\begin{array}{c}\text { Indifference, rigidity, slow to adapt, lack } \\
\text { of new ideas, lack of challenge }\end{array}$ & Low \\
\hline B & $\begin{array}{c}\text { Optimal or } \\
\text { desired }\end{array}$ & Useful & $\begin{array}{c}\text { Dynamic, self-criticism, adaptation, search } \\
\text { for problems solutions, positive move } \\
\text { towards the target }\end{array}$ & High \\
\hline C & High & Harmful & $\begin{array}{c}\text { Random, non-cooperation, activities' } \\
\text { contradiction, difficulty of coordination }\end{array}$ & Low \\
\hline
\end{tabular}

Source: Shalabi, 2011: 97, Al-Otaibi. 2006: 17

\section{The Relationship between Organizational Justice and Organizational Conflict}

As the conflict is a human fact in organizations, and one of the tools of change and modernization, therefore its successful management has become a skill and new function for managers. Scholars such as "Bergman \& Volkma" and "Tatum \& Ebertin: 2006" and "Hody \& Anthony: 1998" found that failure to deal with organizational justice issues is an essential source of conflict. Some researchers such as "Al-Otaibi: 2006" and "Yusuf and Muhammad: 2004" and "Beardawell \& Holden: 2001" and "Alman, David: 2001" confirmed that organizational justice to achieve employees and organization goals, and to effective and acceptable to address the conflict.

Some studies explained that perceived organizational justice is positively linked with cooperative conflict management methods, and linked with different work trends by individuals. Studies such as: - (Rifai, Rajab, 2009) and (Konovsky \& Gropanzano: 1991) and (Barling \& Philps: 1993) and (Totum \& Eberlin: 2006) and (Rahim, Magner \& Shapiro: 2000) and (Rifai, Rajab, 2009) confirmed that there is inverse correlation between organizational justice and conflict level, and there is a positive correlation between organizational justice high level and most cooperative conflict management methods, and whenever organizational justice level is lower, conflict management methods tend to lower cooperation methods (cited in Rifai, Ragab, 2009: 4, 6, 20, 30, from 31.59 to 61)

Based on the above it can be said that organizational justice is linked to positively or inversely with the different variables of the conflict.

\section{Hypotheses Testing}

\subsection{First Hypothesis Test}

Organization justice variables showed variation in the number of their relations and significant level, where the highest correlation coefficient is $(-0.43 * *)$ with individual conflict level, while the lowest correlation coefficient $(-0.061)$ between organizational justice and conflict between groups was not significantly but inversely. This result is consistent with the findings of (Rifai, 2010). Moreover (9) significant relationships have been achieved of the total amounting relations (12) relationship, which far exceeds the half. The links between all organizational justice variables and organizational conflict variables are -inversely which indicates that the rule of justice would reduce organizational conflict level.

-Significant except for its relationship with conflict between groups and the possibility of $p<0.01$.

At the macro level it is noted that relationship between justice and organizational conflict has appeared in three inverse significant relations with conflict at individual level, conflict between individuals, conflict between individual and the group, which interpreted $75 \%$ of relationships. This result provides enough support to prove the first main hypothesis. 
Table 6. The correlation between organizational justice and organizational conflict

\begin{tabular}{|c|c|c|c|c|c|c|c|}
\hline Conflict level & \multirow{2}{*}{\multicolumn{2}{|c|}{$\begin{array}{c}\text { Basic } \\
\text { Relations }\end{array}$}} & \multirow{3}{*}{$\begin{array}{c}\text { Total } \\
\begin{array}{c}\text { Organization } \\
\text { al Conflict }\end{array} \\
* * 0.382-\end{array}$} & \multirow{3}{*}{$\begin{array}{c}\begin{array}{c}\text { Conflict } \\
\text { between groups }\end{array} \\
0.085- \\
\end{array}$} & \multirow{3}{*}{$\begin{array}{c}\text { Conflict } \\
\text { between } \\
\text { individual an } \\
\text { groups } \\
* * 0.292-\end{array}$} & \multirow{3}{*}{$\begin{array}{l}\text { Conflict } \\
* * 0.322-\end{array}$} & \multirow{3}{*}{$\begin{array}{c}\begin{array}{c}\text { Individual } \\
\text { Conflict Level }\end{array} \\
* * 0.427-\end{array}$} \\
\hline Organizational Justice & & & & & & & \\
\hline Distribution Justice & 75 & 3 & & & & & \\
\hline Procedures Justice & 75 & 3 & $* * 0.242$ & $0.007-$ & $* * 0.164$ & $* * 0.252$ & $* * 0.331-$ \\
\hline Transactions Conflict & 75 & 3 & $* * 0.289$ & $0.026-$ & $* * 0.192$ & $* * 0.296-$ & $* * 0.319$ \\
\hline $\begin{array}{c}\text { Total Organizational } \\
\text { Justice }\end{array}$ & & & $* * 0.366$ & $0.061-$ & $* * 0.248$ & $* * 0.348$ & $* * 0.430$ \\
\hline $\begin{array}{c}\text { Basic } \\
\text { Relations }\end{array}$ & - & 9 & 3 & 0 & 3 & 3 & 3 \\
\hline$\%$ & 75 & - & 100 & 0.00 & 100 & 100 & 100 \\
\hline
\end{tabular}

\subsection{Second Hypothesis Test}

Hypothesis indicates that organizational justice and its variables (distributive justice, procedural justice, interaction justice) affect organizational conflict. Multiple regression was used to test the hypothesis, (Table 7) indicates that (F) calculated value (62.379), that is more than tabulated value (2.60). Since the decision rule is to accept the hypothesis if $(F)$ calculated value is greater than the tabulated $t$ value, so the main hypothesis is accepted. The result is supported by the existence of inverse significant correlations $(r=0.382)$ between organizational justice and organizational conflict, which implies that increase in justice and deepening leads to reduction of organizational conflict level. Moreover it was clear that organizational justice variables is associates and affect significantly organizational conflict level as follows:

1-Procedural justice, distributive justice, and interaction justice have significant inverse relationship with organizational conflict. Procedural justice was the strongest (0.373) and the lowest one was distributive justice $(0.279)$

2-There is a significant impact of all organizational justice variables in organizational conflict, and its strength was as follows (procedural justice, interaction justice and distributive justice) respectively.

Table 7. Organizational justice and its variables impact in organizational conflict

\begin{tabular}{cccccccc}
\hline Hypotheses & $\begin{array}{c}\text { R-Squar } \\
\text { e }\end{array}$ & r-Correlation & $\begin{array}{c}\text { Result } \\
\text { Test }\end{array}$ & Sig & Table-F & Calculated-F \\
\hline $\begin{array}{c}\text { The impact of procedural } \\
\text { justice in } \\
\text { Organizational conflict }\end{array}$ & $\% 13.9$ & $* * 0.373$ & Accept & 0.000 & 3.84 & 6.63 & $* * 58.81$ \\
\hline $\begin{array}{c}\text { The impact of distribution } \\
\text { justice in } \\
\text { Organizational conflict }\end{array}$ & $\% 7.5$ & $* 0.279$ & Accept & 0.000 & 3.00 & 4.61 & $* * 30.77$ \\
\hline $\begin{array}{c}\text { The impact of interaction } \\
\text { justice in } \\
\text { Organizational conflict }\end{array}$ & $\% 8.9$ & $* 0.298$ & Accept & 0.000 & 2.60 & 3.78 & $* * 35.379$ \\
\hline $\begin{array}{c}\text { The impact of organizational } \\
\text { justice in }\end{array}$ & $\% 14.6$ & $* 0.382$ & Accept & 0.000 & 2.60 & 3.78 & $* * 62.162$ \\
Organizational conflict & & & & & & & \\
\hline
\end{tabular}

** - is Significant at the 0.01 level (2- tailed). *- is Significant at 0.05 level (2- tailed).

$\mathrm{R}$ - Correlation is Pearson correlation.

\subsection{Third Hypothesis Test}

The main and the sub impact hypothesis state that that organizational justice affect significantly organizational conflict, and the impacts caused by organizational justice will be tested as independent variable on organizational conflict variables as dependent variable using multiple regression to determine impact intense and $\mathrm{t}(\mathrm{F})$ test based on variance analysis (ANOVA) to determine the significant impact. Analysis results related to determination of organizational justice ability to explain the impact variation on all organizational conflict variables (conflict at 
individual level, conflict between individual and group and conflict between groups) with determination coefficient amounting (14.6\%). By reviewing Table 8 , we find that organizational justice ability in interpretation of organizational conflict variables with coefficients determination ranged between $(1 \%-18.6 \%)$ and modified coefficients determination between $(-2 \%-18.4 \%)$, these percentages indicate organizational justice can interpret changes in the organizational conflict variables at the maximum is (18.6\%), despite the decline in these percents, $(\mathrm{F})$ value is greater than (F) calculated value.. Therefore validate the third main hypothesis and sub- the third main hypothesis and the sub hypothesis save the fourth hypothesis are valid

Table 8. Relative impacts of organizational justice in organizational conflict variables

\begin{tabular}{cccccccc}
\hline $\begin{array}{c}\text { Organizational } \\
\text { Conflict Variables }\end{array}$ & Sig & \multicolumn{2}{c}{ F - Table } & F Calculated & Adjusted R & $\begin{array}{c}\text { R } \\
\text { Square }\end{array}$ & D.F \\
\cline { 3 - 4 } $\begin{array}{c}\text { Conflict within the } \\
\text { Individual }\end{array}$ & 0.000 & 6.63 & 3.84 & $* * 83.276$ & $\% 18.4$ & $\% 18.6$ & 364.1 \\
\hline $\begin{array}{c}\text { Conflict between } \\
\text { Individuals }\end{array}$ & 0.000 & 4.61 & 3.00 & $* * 58.913$ & $\% 13.7$ & $\% 13.9$ & 364.1 \\
\hline $\begin{array}{c}\text { Conflict between } \\
\text { individual and groups }\end{array}$ & 0.000 & 3.78 & 2.60 & $* * 26.578$ & $\% 6.5$ & $\% 6.8$ & 364.1 \\
\hline $\begin{array}{c}\text { Conflict between } \\
\text { Groups }\end{array}$ & 0.620 & 3.32 & 2.37 & 0.246 & $\% 0.2$ & $\% 1$ & 364.1 \\
\hline $\begin{array}{c}\text { Justice Interpretation } \\
\text { percent of conflict }\end{array}$ & 0.000 & 3.32 & 2.37 & $* * 62.019$ & $\% 14.3$ & $\% 14.6$ & 364.4 \\
\hline
\end{tabular}

\section{Results \& Recommendations}

\subsection{Results}

The study results can be summarized as follows:

1-A great deal of organizational conflict is due to organizational justice, and thus positive change can be occurred through the reduction of organizational conflict by enhancing organizational justice which is a necessary condition for stability and organizational success.

2- Study variables: level

A - Organizational justice term has positive function, and organizational conflict is a negative function among study sample.

B - There is great agreement on organizational justice weakness and its variables in terms of means which were less than the standard mean, and high intensity of organizational conflict and variables in terms of means, which were more than mean standard (except variable conflict between groups).

3- Organizational justice has inverse relationship with organizational conflict.

4-Organizational justice variables had significant inverse relationship with organizational conflict and variables with (75\%). This clearly indicates that decline in organizational justice of surveyed organizations would inflame tensions and organizational conflict.

5- Organizational justice significantly affects all variables of Organizational conflict except conflict between groups, but such impact was not with high levels.

6- Organizational justice variables (distributive justice, procedural justice, interaction justice) significantly affect organizational conflict

\subsection{Recommendations}

Based on the foregoing results the following is predicted comes from surveyed institutions management:

1- To achieve a balance between organizational justice and organizational conflict because of its contribution in strengthening stability and improving the long-term performance. This recommendation is justified due to sample emphasis on low level of organizational justice and the growing level of organizational conflict 
2- Achieving a state alignment between organizational justice and organizational conflict is based on experienced conditions by study sample which need to be managed or changed up to reach desired equilibrium state, and this requires that analysis and diagnosis of justice and conflict levels existed for cycle balance continuation

3- There is a need of focus management surveyed institutions on organizational justice variables, which proved to be the most influential in organizational conflict level by giving great attention, since there is a weak awareness of these variables importance of leads to give not required importance is for some of these variables at the expense of other variables with significant impact on organizational conflict.level

4- Surveyed institutions management should do measure organizational justice level and estimate the desired organizational conflict level of (do not lead to conflict and instability), and then work on bridging the gap between low level of organizational justice and increased organizational conflict.

\section{References}

Abu Jasser, \& Sabreen Murad Nimer. (2010). Employees perception of organizational justice impact on contextual performance dimensions of. An Empirical Study on ministries staff of Palestinian National Authority in the Gaza Strip, the Islamic University - Gaza, Faculty of Commerce, Department of Business Administration, Master Thesis.

Al Aisha, \& Tariq Ibn Musa. (2006). Organizational conflicts and coping methods, a survey of Directorate General of Passports officers view in Riyadh, Naif Arab University for Security Sciences, Department of Administrative Sciences, Master in 2006. Retrieved from http://www.irqiforem.org

Al- Asri, \& Abdul Malik Ahmad Ali. (2006). The impact of organizational conflict management on job time, Empirical Study on the Ministry of Education in Yemen, Sadat Academy for Administrative Sciences, Master Thesis, 2006. Retrieved from www.yemen-nic.com

Al- Atwi, \& Amer Ali Hussein. (2007). The impact of organizational justice in tourism performance, (analytical study teaching staff members views in the Faculty of Management and Economics, University of Qadisiyah. Qadisiyah Journal for administrative and economic sciences, 10(1).

Al -Bashabashh, \& Samer Abdel Meguid. (2008). The impact of organizational justice in shaping organizational symmetry in Jordanian public institutions, field study. Jordan Journal of Business Administration, 4(4).

Al Harasheh Mohamed Ahmed. (2010, June). Personality style and its impact on organizational conflict, a survey on Jordanian Free Zones Corporation employees. University of Sharjah. Journal of Humanities and Social Sciences, 7(2), Jumada II 1431, 241-277 .

Al- Mahdi, \& Yasser Fathi Al-Hindawi. (2006). Organizational justice and teachers performance of teachers to citizenship behavior in public secondary schools in Egypt, Ph.D. thesis, Ain Shams University, Faculty of Education in 2006. Retrieved from http://kenanaonline.com

Al -Moghrabi Kamel Mohammed. (1995). Organizational behavior, concepts and foundations of individual and group behavior in the organization ( $2^{\text {nd }}$ ed.). Amman, Al Fiker publishing house and distribution.

Albert, S., Ashforth B. E., \& Dutton. J. B. (2000). Organizational identify and identification: charting new water and building new bridges. Academy of management, 25(1), 13-17.

Alkhchrom, Mohammed Mustafa. (2010). The role of interaction justice in reducing role conflict pressures, Empirical Study on elements of nursing at the University Hospital of Aleppo. Damascus University Journal for Economic and Legal Sciences, 26(2), 307-329.

Al-Khereb, \& Mohammed bin Abdullah bin Hamad. (2006). Personal conflicts and their impact on job security, survey on employees attitudes Ministry of Education Divan in Riyadh, Naif Arab University for Security Sciences, Department of Administrative Sciences, Master 2006. Retrieved from www.iraqiforum.org

Al-Otaibi, \& Munira Bint Nayef. (2007). Oganizational conflict management in primary schools for girls in Riyadh, conceived proposal, King Saud University / Department of Educational Administration, Master in 2007. Retrieved from www.ksu.edu.sa

Awamleh, Hamdan, Salem. (2008). Impact of organizational justice on job commitment, a field study in Balqa Applied University. Journal of the Faculty of Education, Al-Azhar University, (136), the first part of July for the year 2008. 
Balawi, Abdel Moneim Jaber. (2009). The concept of organizational conflict, article, dated 4/7/2009. Retrieved from http://www.watein.com

Behaviors: a Study in a Feminine, High Power Distance Culture, Submission of Papers for Publication, University de Santiago. 3810-193 Aveiro. Portugal.

Bruce, Hilton. (2009, January). Archive for organizational conflict. Retrieved from http://organizationalclimat.wordpess.com \& December 2008 /

David, Elman. (2011). Conflict analysis using an organizational justice model applying conflict analysis and diagnostic models \& complaint. processes, (AKNOL) organizational health blogs, Brisbane / Australia, 31- 9 2011. Retrieved from http://knol.google.com

Gul, Hasan. (2011). The effect of employees perception of organizational justice on organizational citizen ship behavior, a. application in Turkish public in situations. International Journal of Business \& Management, 6(6), 134-149.

Harem, Hussein. (1997). Organizational behavior, individuals behavior in organizations. Amman, Zahran House for distribution and publishing.

Hawass, Amira Mohamed Refaat. (2003). The impact of organizational commitment and confidence in management on the relationship between organizational justice and organizational citizenship behaviors, application on commercial banks, Cairo University, Faculty of Commerce, Master Thesis, 2003. Retrieved from http://ugu.edu.sa

Issa, Ibrahim Abdel Fattah Zuhdi. (2009). Organizational conflict management strategies and their relationship to business ethics management, for heads of departments in the faculties of nursing in the Jordanian private universities from the perspective of faculty members, the Middle East University for Graduate Studies, Faculty of Educational Sciences. / 2009. Retrieved from www.meu.edu.jo

John, Onne. (2004). The Barrier effect of conflict with superiors in the relationship between employers empowerment and organizational commitment. Work and Stress, 18, 56-60.

Kareeman, D., \& Alvesson, M. (2001). Making newsmakers conversational identify At work. Organization Studies, 22, 60-70.

Kashlaf Abdul Hamid. (2009). The concept of conflict and its nature of the article on 19/1/2009. Retrieved from www.hrdiscussion/hr3919.html

Lee, H. R. (2000). An empirical study of organizational justice as mediator of the relationship among leader member exchange and job satisfaction organization commitment and turnover intentions in the lodging industry, unpublished dissertation, faculty of the Virginia polytechnic institute and state university.

Mohammad Qasim Qaryouti. (1997). Organizational behavior, the study of human behavior of individual and collective management organizations. Amman, Al Shrouqe House, 2nd Floor.

Naqbil, Bu Jumaah. (2009). Organizational climate relationship with conflict management style, in Algerian public secondary schools, field study, in Masilad state high schools, the University of Haj Akhdhar, Algeria, Batna, Master in 2009.

Niehoff, B., \& Moorman, R. Justice. (1993). As a mediator of the relationship between methods of monitoring and organization citizenship Behavior. Academy of management Journal, 36(2), 527 - 556.

Nimer Saud bin Mohammed. (1994). Organizational conflict: factors and management methods, Journal of King Abdul Aziz University. Economics and Management, 7, 37 - 91 in 1994/1414.

Qutb, Mohammed. An article entitled the need for human conflict. Retrieved from www.balagh.com/deen/4i0op4onhtm

Rafii, Mustafa. (2010). Islam and justice, essay, 2010, Retrieved from www.balagh.com/deen/zh04zxi8.htm

Rahim, M. Manger, N., \& Shapiro, D. (2000). Do Justice perceptions influence styles: of handling conflict with supervisors?: what Justice perceptions, precisely? The International Journal of conflict management, 11(1), 9-32.

Rego, A., \& Cunha, M. (2006). Organizational Justice and Citizenship. 
Rifai, Rajab Hassanein Mohamed Rifai. (2010). Analysis of relationship between organizational justice and organizational levels and methods of conflict management, field study, Arab Journal of Management, a special version of the Arab Organization for Administrative Development in Cairo in 2010.

Sarayreh, Aktham Abdel Meguid. (2008, January). Political behavior and its impact on organizational conflict level, an analytical study of XIV. Jordanian Parliament Journal of Studies, 35(1), University of Jordan, Administrative Sciences.

Saud, Rated, \& Sultan Susan. (2009). Organizational justice degree among heads of academic departments in the official Jordanian universities and their relationship to organizational loyalty to the faculty members. Damascus University Journal, 25(1+2).

Shaima, the concept of organizational justice, intervention in 2006 Update 2008. Retrieved from /http://www.hrm-group.com

Shalabi, Zuhair Bo Jumaah. (2011). Organizational conflict management organization. Amman, Dar Yazouri.

Sharif, Najla Ali Rafed. (1999). Organizational conflict in academic institutions, applied study at King Saud University, Master 1999/1419. Retrieved from http://raci.kau.edu.sa/

Taamna, Mohamed Chaoui and dreams. (2001). The level of practice of organizational justice from the perspective of workers in the Ministry of Planning and Development Cooperation of Iraq, Egypt, Cairo, the Arab Organization for Administrative Development, i 1.

Thierry Nadisic. HEC school of Management, pari, france - The motives, organizational Justice Thierry. nadisic @ tiscali.fr. pp 5-7. Retreived from http://www.hec.fr/...

Timothy A. Judge, \& Jason, A. (2004). Colquitt, organizational Justice and stress: the Medialing role of work Family conflict. Journal of Applied psychology. 89(3), 395-404.

Wadi, Rushdie Abdul Latif. (2007). Organizational justice, a field study on Palestinian ministries in the Gaza Strip. Journal of Business Research contemporary, University of Sohag, 21(1). Retreived from http://site.iugaza.edu.ps

Weshahi, Marwan Issa. (2002). Organizational conflict management with the moderators and the Ministry of Youth and Sports in Palestine, An-Najah National University, Master. Retrieved from www.mediatire.com

Zayed, Adel Mohammed. (2006). Organizational justice is the future task of human resources management. Cairo, publications of Arab Organization for Administrative Development (Special Issue). 